\title{
MAQAMAT (TINGKATAN SPIRITUALITAS DALAM PROSES BERTASAWUF)
}

\author{
Hana Widayani* \\ E-mail: hanawidayani@gmail.com
}

\begin{abstract}
Abstrak
Tasawuf merupakan salah satu bidang kajian Islam yang menjadi daya tarik tersendiri untuk dikaji. Ia merupakan salah satu tema yang mendapatkan perhatian luas baik di kalangan peneliti muslim, maupun non-muslim. Namaun demikian, hal ini pada akhirnya mempunyai konsekuensi tersendiri terhadap pemahaman tasawuf, yang terkadang bertentangan dengan pemahaman para pengamal tasawuf, dalam hal ini adalah sufi. Sebagaimana pendapat Nicholson misalnya, yang menyatakan bahwa salah satu maqamat yang ada di dalam tasawuf, yaitu az-Zuhd, merupakan ajaran yang juga telah dipraktikan dan ditemukan dalam penganut agama yang lain, dalam hal ini adalah Kristen. Tulisan ini akan berupaya membahas konsep maqamat dan ahwal dalam perspektif para sufi dalam proses bertasawufnya, yang bertujuan untuk melihat apakah konsep maqamat dan ahwal ini mendapatkan pengaruh dari agama lain di luar Islam, atau justru sebaliknya bahwa ia muncul secara original dari ajaran Islam itu sendiri.
\end{abstract}

Kata Kunci: Maqamat, Ahwal, Tasawuf

\section{Pendahuluan}

Tasawuf merupakan salah satu fenomena dalam Islam yang memusatkan perhatian pada pembersihan aspek rohani manusia, yang selanjutnya menimbulkan akhlak mulia. Melalui tasawuf ini seseorang dapat mengetahui tentang caracara melakukan pembersihan diri serta mengamalkan secara benar. Banyak pengertian tasawuf yang dirumuskan oleh ulama tasawuf, tetapi tidak mencakup pengertian tasawuf secara menyeluruh.

Tinjauan analitis terhadap tasawuf menunjukkan bahwa para sufi dengan berbagai aliran yang dianutnya memiliki suatu konsepsi tentang jalan (thariqat) menuju Allah. Jalan ini dimulai dengan latihan-latihan rohaniah, lalu secara bertahap menempuh berbagai fase, yang dikenal dengan maqam dan hal, dan berakhir dengan mengenal (ma'rifat) kepada Allah. Tingkat pengenalan (ma'rifat) menjadi jargon yang umumnya banyak dikejar oleh para sufi. Kerangka sikap dan perilaku sufi diwujudkan melalui amalan dan metode tertentu yang disebut thariqat, atau jalan untuk menemukan pengenalan (ma'rifat) Allah. Lingkup perjalanan menuju Allah untuk memperoleh pengenalan (ma'rifat) yang berlaku di kalangan sufi sering disebut sebagai sebuah kerangka'Irfani.

Lingkup 'Irfani tidak dapat dicapai dengan mudah atau secara spontanitas, 
tetapi melalui proses yang panjang. Proses yang dimaksud adalah maqammaqam (tingkatan atau stasiun) dan ahwal (jama' dari hal). Dua persoalan ini harus dilewati oleh seorang sufi yang berjalan menuju Tuhan.

Namun

dicatat, maqam dan hal tidak perlu dapat dipisahkan. Keduanya ibarat dua sisi dalam satu mata uang. Keterkaitan antar keduanya dapat dilihat dalam kenyataan bahwamaqam menjadi prasyarat menuju Tuhan dan dalam maqam akan ditemukan kehadiran hal. Hal yang telah ditemukan dalam maqam akan mengantarkan seseorang untuk mendaki maqammaqam selanjutnya. Untuk itu pemakalah akan membahas tentang maqam dan ahwal dalam tasawuf.

\section{A. Maqamat}

\section{Pengertian Maqamat}

Secara harfiah maqamat berasal dari bahasa Arab yang berarti, tempat orang berdiri atau pangkal mulia. ${ }^{1}$ Dalam bahasa Inggris maqamat dikenal dengan istilah stages yang berarti tangga. Sedangkan dalam ilmu Tasawuf, maqamat berarti kedudukan hamba dalam pandangan Allah berdasarkan apa yang telah diusahakan, baik melalui riyadhah, ibadah, maupun mujahadah. ${ }^{2}$ Istilah ini selanjutnya digunakan untuk arti sebagai jalan panjang yang harus ditempuh oleh seorang sufi untuk berada dekat dengan Allah. ${ }^{3}$

\section{Jumlah Maqamat Dalam Tasawuf}

Tentang berapa jumlah tangga atau maqamat yang harus ditempuh oleh seorang sufi untuk sampai menuju Tuhan, di kalangan para sufi tidak sama pendapatnya. Muhammad al-Kalabazy dalam kitabnya al-Ta'arruf li Mazhab ahl alTasawwuf, sebagai dikutip Harun Nasution misalnya mengatakan bahwa maqamat itu jumlahnya ada sepuluh, yaitu al-taubah, al-zuhud, al-shabr, al-faqr, altawadlu', al-taqwa, al-tawakkal, al-ridla, almahabbah dan al-ma'rifah. ${ }^{4}$

Sementara itu Abu Nasr al-Sarraj alTusi dalam kitabal-Luma', sebagaimana yang dikutip oleh Harun Nasution menyebutkan jumlah maqamat hanya tujuh, yaitu al-taubah, al-shabr, alwara', al-zuhud, al-faqr, al-tawakkal dan alridla. ${ }^{5}$ Adapun menurut Imam al-Ghazali dalam kitabnya Ihya' Ulum al-Din, dalam buku Abudin Nata, mengatakan bahwa maqamat itu ada delapan, yaitu al-taubah, al-shabr, al-zuhud, al-faqr, al-tawakkal, almahabbah, al-ma'rifah, dan al-ridla. ${ }^{6}$

Jumlah maqamat tersebut di atas memperlihatkan keadaan variasi penyebutan maqamat yang berbeda-beda, namun ada maqamat yang oleh mereka 
disepakati, yaitual-taubah, al-zuhud, alwara, al-faqr, al-shabr, al-tawakkal dan alridha. Sedangkan al-tawaddlu, al-mahabbah, dan al-ma'rifah oleh mereka tidak disepakati sebagai maqamat. Terhadap tiga istilah yang disebut terakhir itu (altawaddlu, al-mahabbah dan al-ma'rifah) terkadang para ahli tasawuf menyebutnya sebagai maqamat, dan terkadang menyebutnya sebagai hal dan ittihad (tercapainya kesatuan wujud rohaniah dengan Tuhan). Untuk itu dalam uraian ini, maqamat yang akan dijelaskan lebih lanjut adalah maqamat yang disepakati oleh mereka, yaitu al-taubah, al-zuhud, alwara', al-faqr, al-shabr, al-tawakkal, dan alridha. Penjelasan atas masing-masing istilah tersebut dapat dikemukakan sebagai berikut: ${ }^{7}$

- Al-Taubah

Al-Taubah berasal dari Bahasa Arab taba-yatubu-taubatan yang berarti "kembali" dan "penyelesalan". 8 Sedangkan pengertian taubat bagi kalangan sufi adalah memohon ampun atas segala dosa yang disertai dengan penyesalan dan berjanji dengan sungguh-sungguh untuk tidak mengulangi perbuatan dosa tersebut dan dibarengi dengan melakukan kebajikan yang dianjurkan oleh Allah. ${ }^{9}$ Harun Nasution, mengatakan bahwa taubat yang dimaksud kalangan sufi ialah taubat yang sebenarnya, taubat yang tidak akan membawa kepada dosa lagi. ${ }^{10}$

menurut al-Quyairi, makna taubat adalah kembali. Ia bertaubat, artinya ia kembali, yaitu kembali dari sesuatu yang dicela dalah syariat menuju sesuatu yang dipuji dalam syariat. ${ }^{11}$ Syarat yang harus dipenuhi agar taubatnya diterima adalah menyesali pelanggaran yang telah dilakukan, meninggalkan secara langsung penyelewengan tersebut dan kemudian dengan mantap ia memutuskan untuk tidak kembali kepada kemaksiatan yang sama. ${ }^{12}$

Bagi orang awam taubat dilakukan dengan membaca istighfar (astagfirullah waatubu ilahi). Sedangkan bagi orang khawas (orang yang telah menjadi sufi) bertaubat dengan melakukan riyadhah (latihan) dan mujahadah (perjuangan) dalam rangka membuka hijab yang membatasi dirinya dengan Allah SWT. Taubat ini dilakukan para sufi hingga mampu menggapai maqam yang lebih tinggi. ${ }^{13}$ Bagi golongan khawas yang dipandang dosa adalah ghaflah (terlena mengingat Allah) sumber munculnya segala dosa. Dengan demikian taubat merupakan pangkal tolak peralihan dari hidup lama ke kehidupan baru secara sufi. Yaitu hidup selalu ingat kepada Allah sepanjang masa. ${ }^{14}$ 
Adapun menurut al-Ghazali taubat intinya adalah penyesalan, sesuai dengan sabda Nabi, " Taubat adalah penyesalan". Menyesali perbuatan dosa yang dilakukan di masa lalu, meninggalkan dosa kini dan berketetapan hati untuk tidak mengulangnya. ${ }^{15}$

Berkaitan dengan maqam taubat, dalam al-Qur'an terdapat banyak ayat yang menjelaskan masalah ini, di antaranya adalah ayat yang berbunyi:

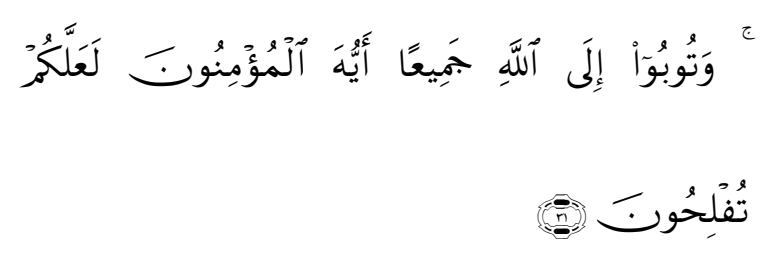

Artinya: Dan bertaubatlah kamu sekalian kepada Allah, Hai orang-orang yang beriman supaya kamu beruntung. (QS. AnNur: 31)

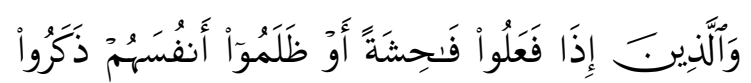

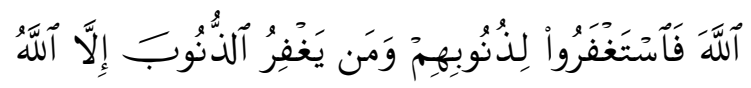

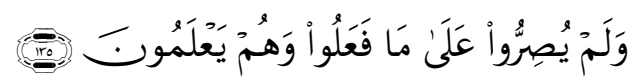

Artinya: Dan (juga) orang-orang yang apabila mengerjakan perbuatan keji atau menganiaya diri sendiri, mereka ingat akan Allah, lalu memohon ampun terhadap dosadosa mereka dan siapa lagi yang dapat mengampuni dosa selain dari pada Allah? dan mereka tidak meneruskan perbuatan kejinya itu, sedang mereka mengetahui. (Ali Imron: 135). ${ }^{16}$

- Al-Zuhud

Secara etimologis, zuhud berarti ragaba 'ansyai'in wa tarakahu, artinya tidak tertarik terhadap sesuatu dan meninggalkannya. Zuhada fi al-dunya, berarti mengosongkan diri dari kesenangan dunia untuk ibadah. ${ }^{17}$ Zuhud dalam pandangan para sufi berarti meninggalkan kehidupan dunia dan berkonsentrasi kepada kehidupan akhirat. ${ }^{18}$

Adapun dalam mengartikan zuhud para sufi dan ulama berbeda pendapat, diantaranya al-Ghazali, menurutnya hakikat zuhud adalah tidak menyukai sesuatu, dan menyerahkannya kepada yang lain. Barabgsiapa yang meninggalkan kelebihan dunia dan membencinya, lalu mencintai akhirat, maka ia adalah orang zuhud di dunia. Derajat zuhud tertinggi adalah tidak menyukai segala sesuatu selain Allah SWT. Di dalam kezuhudan harus diketahui bahwa akhirat adalah lebih baik daripada dunia. Dan perbuatan yang muncul dari suatu hal merupakan kessempurnaan kecintaan pada akhirat. ${ }^{19}$

Sedangkan menurut Harun Nasution, zuhud artinya keadaan meninggalkan dunia dan hidup 
kematerian. ${ }^{20}$ lain halnya dengan alKalabadzi, dalam buku Mulyadhi Kartanegara, mengatakan bahwa zuhud adalah cara hidup yang bersahaja, dalam arti bahwa ia meninggalkan sesuatu yang bisa ditinggalkan, dan mempertahankan hanya yang tak bisa ditinggalkan.21

Berkaitan dengan konsep zuhud, dalam al-Qur'an terdapat ayat yang menjelaskan hal itu, di antaranya:

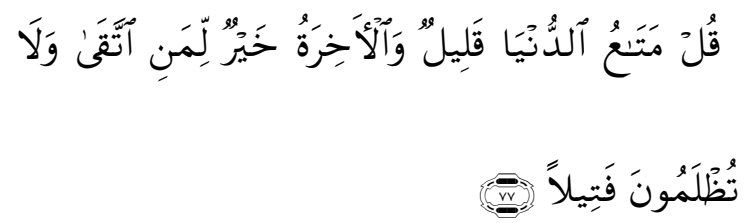

Artinya: Katakanlah kesenangan di dunia ini hanya sebentar dan akhirat itu lebih baik bagi orang-orang yang bertakwa, dan kamu tidak akan dianiaya sedikitpun. (QS. An-Nisa': 77)

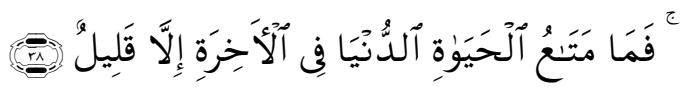

Artinya: Padahal kenikmatan hidup di dunia ini (dibandingkan dengan kehidupan) diakhirat hanyalah sedikit. (QS. Al-Taubah: 38). ${ }^{22}$

\section{- Al-Wara'}

Secara harfiah al-wara' artinya saleh, menjauhkan diri dari perbuatan dosa. Yang mengandung arti menjauhi hal-hal yang tidak baik. Dan dalam pengertian para sufi, al-wara' adalah meninggalkan segala yang ada di dalamnya terdapat keragu-raguan antara halal dan haram (syubhat). Sikap menjauhi diri dari yang syubhat ini sejalan dengan hadis Nabi yang artinya: Barangsiapa yang dirinya terbebas dari syubhat, maka sesungguhnya ia telah terbebas dari yang haram. (HR. Bukhari). ${ }^{23}$

Kemudian menurut Sayyed Husein Nasr, wara' adalah rendah diri, mereka para sufi tidak makan makanan apapun, tak memakai kain apapun. Mereka tidak ikut berkumul dalam pergaulan sembarangan orang dan mereka tidak memiliki persahabatan dengan siapapun kecuali Tuhan. ${ }^{24}$ Maksud dari penjelasan di atas bukan berarti tidak makan sama sekali dan tidak memakai pakaian sama sekali dalam hidupnya, akan tetapi hanya tidak ingin berlebihan dalam soal makanan dan pakaian.

\section{- Al-Faqr}

Secara harfiah, fakir diartikan sebagai orang yang berhajat, butuh atau orang miskin. ${ }^{25}$ Berarti sebagai kekurangan harta yang diperlukan seseorang dalam menjalani kehidupan di dunia. Sikap ini menjadi penting dimiliki orang yang sedang berjalan menuju Allah. ${ }^{26}$

Sedangkan dalam pandangan sufi, fakir adalah tidak meminta lebih dari apa yang telah ada pada diri kita. Tidak 
meminta rezeki kecuali hanya untuk dapat menjalankan kewajiban-kewajiban. Tidak meminta sungguhpun tak ada pada diri kita, kalau diberi diterima. Tidak meminta tetapi tidak menolak. ${ }^{27}$

Dalam risalah al-Qusyairiyah, maqam fakir dibahas agak panjang lebar, salah satunya adalah menurut Dzun Nun al-Misri, ia berkata,"Selalu butuh kepada Allah dengan memakan makanan yang tiak enak lebih baik bagiku darpada selalu suci disertai dengan ujub." Adapun menurut Ahamd An-Nuri, "Sifat orang fakir itu jika tidak ada, ia diam. Jika memiliki sesuatu, ia menafkahkannya dan lebih mengutamakan orang lain." 28

Sedangkan menurut al-Ghazali yang paling tinggi dari keadaan orang fakir adalah keberadaan dan ketiadaan harta baginya sama saja, baik sedikit harta di tangannya maupun banyak, ia tidak peduli, tetapi tidak menghindari untuk mencarinya, dan tidak memikirkan kepentingannya sendiri. ${ }^{29}$

\section{- Al-Shabr}

Secara harfiah, sabar artinya tabah hati. ${ }^{30}$ Menurut Dzun Nun al-Misri, sabar artinya menjauhkan diri dari hal-hal yang bertentangan dengan kehendak Allah, tetapi tenang ketika mendapatkan cobaan, dan menampakkan sikap cukup walaupun sebenarnya bearda dalam kefakiran dalam bidang ekonomi. ${ }^{31}$
Sedangkan

al-Kalabadzi, mengatakan bahwa sabar adalah pengharapan akan kesenangan atau kegembiraan dari Allah, dan ini merupakan pengabdian yang paling mulia dan paling tinggi. Tetapi sabar pada tingkat yang lebih tinggi adalah 'sabar atas kesabaran' maksudnya seseorang tiak seharusnya mencari kesenangan atau kegembiraan apa pun. ${ }^{32}$

Di kalangan para sufi, sabar diartikan sabar dalam menjalankan perintah-perintah Allah, dalam menjauhi segala larangan-Nya, dan dalam menerima segala percobaan yang ditimpakan-Nya pada diri kita. ${ }^{33}$ Sabar merupaka alah satu dari sekian maqamat untuk menuju kepada ma'rifat. Dengan kesabaran seseorang akan menjadi lebih terang hatinya sehingga lebih mudah dalam meyakini ke-Agungan Allah. ${ }^{34}$

Sikap sabar sangat dianjurkan dalam ajaran al-Qur'an, Allah berfirman;
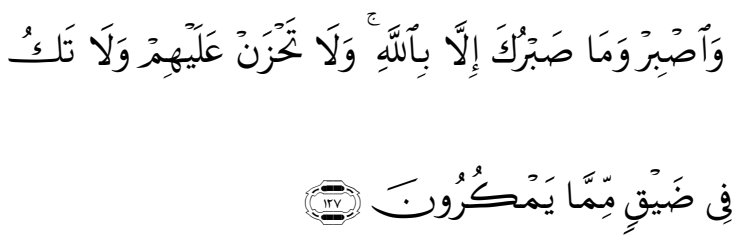

Artinya: Bersabarlah dan Tiadalah kesabaranmu itu melainkan dengan pertolongan Allah dan janganlah kamu bersedih hati terhadap (kekafiran) mereka dan janganlah kamu bersempit dada terhadap apa 
yang mereka tipu dayakan. (QS. AnNahl: 127)

- Al-Tawakal

Secara harfiah tawakal berarti menyerahkan diri. ${ }^{35}$ Tawakal merupakan gambaran keteguhan hati manusia dalam menggantungkan diri hanya kepada Allah. ${ }^{36}$

Menurut al-Qusyairi tempat tawakal di dalam hati, dan timbulnya gerak dalam perbuatan tidak mengubah tawakal yang terdapat dalam hati itu. Hal itu terjadi setelah hamba meyakini bahwa segala ketentuan hanya didasarkan pada ketentuan Allah. Mereka menganggap jika menghadapi kesulitan maka yang demikian itu sebenarnya takdir Allah. ${ }^{37}$

Dalam hal tawakal, al-Ghazali mengaitkannya dengan tauhid, bahwa hakikat tauhid sebagai landasan tawakal. Makna tauhid yang merupakan pokok tawakal adalah perwujudan dari ucapanmu yaitu La ilaha illallah wahdahu la syarika lahu. 38 Lain halnya dengan alKalabadzi, menurutnya tawakal adalah meninggalkan segala daya upaya dengan mengatakan "la haula wa la quwwata illa billah" (tidak ada daya dan upaya kecuali dari Allah). Tawakal adalah mencampakkan segala perlindungan kecuali kepada Allah. ${ }^{39}$

Bertawakal termasuk perbuatan yang diperintahkan oleh Allah. Dalam firman-Nya, Allah menyatakan;

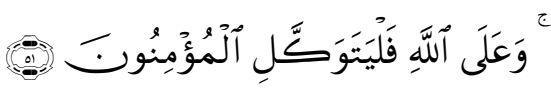

Artinya: dan hanyalah kepada Allah orang-orang yang beriman bertawakal." (QS. At-Taubah: 51)

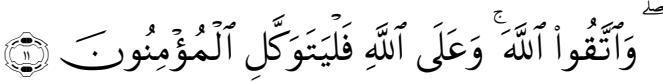

Artinya: dan bertakwalah kepada Allah, dan hanya kepada Allah sajalah orang-orang mukmin itu harus bertawakkal. (QS. AlMaidah: 11). ${ }^{40}$

- Al-Ridha

Secara harfiah, ridha artinya rela, suka, dan senang. ${ }^{41}$ Berarti menerima dengan rasa puas terhadap apa yang dianugerahkan Allah SWT. Orang yang rela mampu melihat hikmah dan kebaikan dibalik cobaan yang diberikan Allah kepada kita. ${ }^{2}$

Ridha menurut al-Kalabadzi adalah diamnya hati dalam guratan nasib. Atau seperti yang dikatakan Dzun Nun alMisri, ridha adalah rasa senang hati dalam menjalani nasib. ${ }^{43}$ Bagi para sufi, cobaan dan musibah dianggap sebagai suatu nikmat bukan suatu kepahitan/kesakitan, lantaran dengan cobaan-cobaan itu 
mereka yakin bahwa Allah menyayangi kita dan bila kita ridha, maka kita akan semakin dekat dengan-Nya. Seseorang yang telah ridha tidak akan pernah merasa berduka cita, dia selalu bergembira, karena ia meyakini apa yang sedang dialami dan atau diperoleh, meskipun berupa derita dan bencana adalah hal yang terbaik baginya. ${ }^{44}$ Orang yang telah mencapai maqam ini akan senantiasa bahagia dan tidak susah walaupun ia telah beramal baik dan masuk ke dalam neraka, dan tidak begitu bahagia walaupun ia nantinya masuk surga.

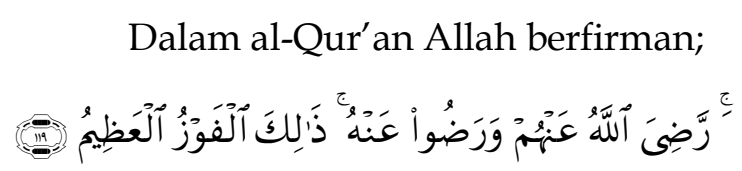

Artinya: Allah ridha kepada mereka dan mereka ridha kepada-Nya. Itulah kemenangan yang besar. (QS. Al-Maidah: 119).

\section{B. Hal (Ihwal)}

\section{Pengertian $\mathrm{Hal}$}

Secara bahasa ahwal adalah bentuk jamak dari kata hal, yang artinya sifat dan keadaan jiwa sesuatu. 45 Yang dimaksud disini adalah keadaan atau kondisi psikologis yang dirasakan ketika seorang sufi mencapai maqam tertentu. Adapun menurut para sufi, hal adalah makna, nilai atau rasa yang hadir dalam hati secara otomatis, tanpa unsure kesengajaan, upaya, latihan, dan pemaksaan, seperti rasa gembira, rindu, takut, dan sebagainya. Keadaan tersebut merupakan pemberian, sedangkan maqam adalah hasil usaha. Hal (keadaan) datang dari Allah dengan sendirinya, sementara maqam terjadi karena pencurahan perjuangan yang terus-menerus. Para guru sufi menyatakan bahwa hal, sebagaimana namanya menunjukkan arti tentang sesuatu (rasa, nilai, getaran) yang menguasai hati kemudian hilang. ${ }^{46}$

\section{Jumlah Hal Dalam Tasawuf}

Sebagaimana

halnya dengan maqamat, dalam penentuan hal juga terdapat perbedaan pendapat di kalangan para sufi. Menurut Abu Nasr alSarraj dalam kutipan Sayyid Husein Nasr, menyebutkan beberapa tingkatan jiwa (ahwal) yaitu; mawas diri (muraqabah), cinta (mahabbah), takut (khauf), harapan (raja'), rindu (shauq), karib (uns), ketenangan (itmi'nan), perenungan (mushahadah) dan kepastian (yaqin). ${ }^{47}$

Berikut penjelasan singkat dari beberapa hal tersebut:

- Mawas diri (muraqabah)

Mawas diri adalah meneliti dengan cermat apakah segala perbuatan yang telah dilakukan setiap hari sudah sesuai dengan aturan-aturan-Nya atau 
malah menyimpang dari yang dikehendaki-Nya. ${ }^{48}$

Al-Qusyairi mengatakan bahwa muraqabah adalah ilmu hamba untuk melihat Allah SWT. Sedangkan yang konsisten terhadap ilmu itu adalah yang mengawasi (menjaga atau merasa dirinya selalu diawasi sehingga membentuk sikap yang selalu awas pada hukum-hukum Allah) ini merupakan dasar tiap-tiap kebaikan. 49

Allah SWT berfirman;

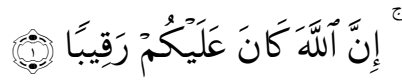

Artinya: "Sesungguhnya Allah selalu menjaga dan mengawasi kamu". (QS. AnNisa': 1).

- Cinta (Mahabbah)

Bagi para sufi, cinta pada dasarnya adalah anugerah yang menjadi dasar pijakan bagai segenap hal. Mahabbah adalah kecenderungan hati untuk memperhatikan keindahan atau kecantikan. ${ }^{0}$ Adapun makna cinta menurut al-Ghazali adalah kecenderungan jiwa pada-Nya karena keberadaan-Nya sebagai suatu kelezatan pada-Nya. ${ }^{51}$ Bahwa Kecintaan karena Allah merupakan tujuan utama. Itu termasuk dari derajat-derajat yang tinggi.

Berbeda halnya dengan al-Qusyairi, menurutnya cinta adalah suatu hal yang mulia. Allah Yang Maha Suci menyaksikan cinta hamba-Nya dan Allah pun memberitahukan cinta-Nya kepada hamba itu. Kecintaan seorang hamba kepada Allah tidak mengandung suatu kecenderungan. Bagaimana mungkin mengandung, sedangkan hakikat ketinggian Allah tidak bisa bertemu dengan-Nya. Karena itu seorang hamba yang mencintai Allah akan tenggelam dalam cinta-Nya. ${ }^{52}$

Dalam al-Qur'an telah jelas bahwa Allah berfirman;

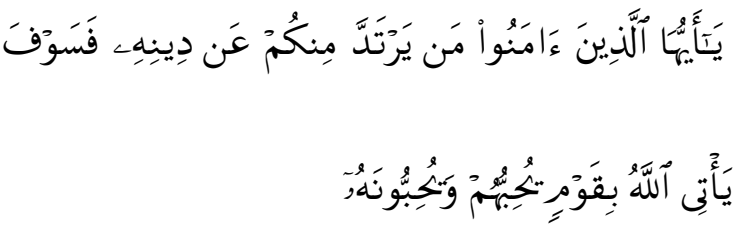

Artinya: Hai orang-orang yang beriman. Barangsiapa di antara kamu yang murtad dari agamanya, Maka kelak Allah akan mendatangkan suatu kaum yang Allah mencintai mereka dan merekapun mencintaiNya. (QS. Al-Maidah: 54).

- Berharap dan Takut (raja' dan khauf)

Menurut kalangan para sufi, raja' dan khauf berjalan seimbang dan saling mempengaruhi. Raja' atau optimisme adalah perasaan senang hati yang senang karena menanti sesuatu yang diinginkan dan disenangi. 
Raja' atau optimisme ini telah ditegaskan dalam al-Qur'an:
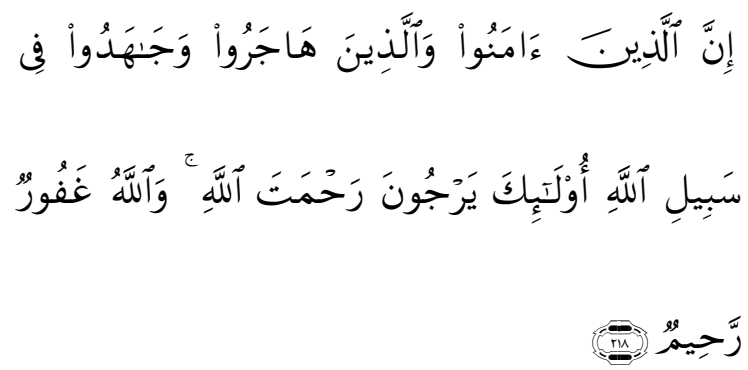

Artinya: Sesungguhnya orang-orang yang beriman, orang-orang yang berhijrah dan berjihad di jalan Allah, mereka itu mengharapkan rahmat Allah, dan Allah Maha Pengampun lagi Maha Penyayang. (QS. AlBaqarah: 218)

Orang yang harapan dan penantiannya mendorongnya untuk berbuat ketaatan dan mencegahnya dari kemaksiatan, berarti harapannya benar. Sebaliknya, jika harapannya hanya anganangan, semenatara ia sendiri tenggelam dalam lembah kemaksiatan, harapannya sia-sia.

Raja' menunut tiga perkara, yaitu:

a. Cinta kepada apa yang diharapkannya.

b. Takut bila harapannya hilang.

c. Berusaha untuk mencapainya.

Raja' yang tidak dibarengi dengan tiga perkara itu hanyalah ilusi atau hayalan. Setiap orang yang berharap adalah juga orang yang takut (khauf). ${ }^{53}$
Sedangkan khauf adalah bayangan perasaan terhadap sesuatu yang ditakuti yang akan menimpa dirinya. Jadi khauf ini bisa mencegah seseorang berbuat maksiat karena takut akan siksaan yang akan ia dapatkan jika melakukan hal tersebut.

Raja' dan khauf saling berhubungan. Apabila sikap raja' terlalu besar, maka akan menjadikan orang tersebut sombong dan meremehkan hal-hal yang lain. Begitu pula dengan khauf menyebabkan seseorang lalai dan berani berbuat maksiat, sedangkan khauf yang berlebihlebihan menjadikan orang tersebut pesimis dan putus asa. 54

- Rindu (shauq)

Menurut al-Qusyairi, rindu adalah kegoncangan hati untuk menemui yang dicintai. Kerinduan tergantung dalamnya cinta. ${ }^{55}$ Selama masih ada cinta, shauq tetap diperlukan. Dalam lubuk jiwa seorang sufi, rasa rindu hidup dengan subur, yakni rindu untuk segera bertemu dengan Tuhan. Ada orang yang mengatakan bahwa maut merupakan bukti cinta yang benar dan lupa kepada Allah lebih berbahaya daripada maut. Bagi sufi yang rindu kepasa Tuhan, maut dapat mempertemukannya dengan Tuhan, sebab hidup merintangi pertemuan 'abid dengan $M a^{\prime} b u d$-nya. ${ }^{56}$

Sehubungan dengan ayat yang menegaskan tentang pertemuan dengan 
Allah, dalam berfirman-Nya yang berbunyi;

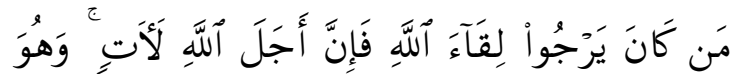

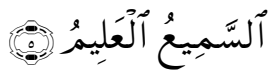

Artinya: Barangsiapa yang mengharap Pertemuan dengan Allah, Maka Sesungguhnya waktu (yang dijanjikan) Allah itu, pasti datang. dan Dialah yang Maha mendengar lagi Maha mengetahui. (QS. AlAnkabut: 5).

- Karib (uns)

Uns (suka cita) dalam pandangan sufi adalah sifat merasa selalu berteman, tak pernah merasa sepi. Dalam keadaan seperti ini, seorang sufi merasakan tidak ada yang dirasa, tidak ada yang diingat, tidak ada yang diharap kecuali Allah. Segenap jiwa terpusat kepada-Nya, sehingga ia seakan-akan tidak menyadari dirinya lagi dan berada dalam situasi hilang kesadaran terhadap alam sekitarnya. Situasi kejiwaan seperti itulah yang disebutal-Uns. Ada sebuah ungkapan yang menggambarkan alUns sebagai berikut: "Ada orang yang merasa sepi dalam keramaian. Ia adalah orang yang selalu memikirkan kekasihnya, sebab sedang dimabuk cinta, seperti halnya sepasang pemuda dan pemudi. Ada pula orang yang bising dalam kesepian. Ia adalah orang selalu memikirkan atau merencanakan tugas pekerjaannya semata-mata. Adapun engkau selalu berteman di manapun berada. Alangkah mulianya engkau berteman dengan Allah. Artinya engkau selalu berada dalam pemeliharaan Allah. Seorang hamba yang merasakan Uns, dibedakan menjadi tiga kondisi; Pertama, seorang hamba yang merasakan suka cita berzikir mengingat Allah dan merasa gelisah di saat lalai. Merasa senang di saat berbuat ketaatan dan gelisah berbuat dosa. Kedua, seorang hamba yang merasa senang dengan Allah dan gelisah terhadap bisikan-bisikan hati, pikiran dan segala sesuatu selain Allah yang akan menghalanginya untuk dekat dengan Allah. Ketiga, yaitu kondisi yang tidak lagi melihat suka citanya karena adanya wibawa, kedekatan, kemuliaan dan mengagungkan disertai dengan suka cita. 57

- Ketenangan (Thuma'ninah)

Thuma'ninah adalah rasa tenang, tidak ada rasa was-was atau khawatir, tak ada yang dapat mengganggu perasaan dan pikiran, karena ia telah mencapai tingkat kebersihan jiwa yang paling tinggi. Seseorang yang telah mencapai tingkatan thuma'ninah, ia telah kuat akalnya, kuat imannya dan ilmunya serta bersih 
ingatannya. Jadi, orang tersebut merasakan ketenangan, bahagia, tentram dan ia dapat berkomunikasi langsung dengan Allah. Thuma'ninah dibagi menjadi tiga tingkatan; Pertama, ketenangan bagi kaum awam. Ketenangan ini didapatkan ketika seorang hamba berzikir, mereka merasa tenang karena buah dari berzikir adalah terkabulnya doa-doa. Kedua, ketenangan bagi orang-orang khusus. Mereka di tingkat ini merasa tenang karena mereka rela, senang atas keputusan Allah, sabar atas cobaan-Nya, ikhlas dan takwa. Ketiga, ketenangan bagi orang-orang paling khusus. Ketenangan di tingkat ini mereka dapatkan karena mereka mengetahui bahwa rahasiarahasia hati mereka tidak sanggup merasa tentram kepada-Nya dan tidak bisa tenang kepada-Nya, karena kewibawaan dan keagungan-Nya. ${ }^{58}$

- Penyaksian (Musyahadah)

Musyahadah secara harfiah adalah menyaksikan dengan mata kepala. Secara terminologi, tasawuf adalah menyaksikan secara jelas dan sadar apa yang dicarinya (Allah) atau penyaksian terhadap kekuasaan dan keagungan Allah. Seorang sufi telah mencapai musyahadah ketika sudah merasakan bahwa Allah telah hadir atau Allah telah berada dalam hatinya dan seseorang sudah tidak menyadari segala apa yang terjadi, segalanya tercurahkan pada yang satu, yaitu Allah, sehingga tersingkap tabir yang menjadi senjangan antara sufi dengan Allah. Dalam situasi seperti itu, seorang sufi memasuki tingkatan ma'rifat, di mana seorang sufi seakan-akan menyaksikan Allah dan melalui persaksiannya tersebut maka timbullah rasa cinta kasih. ${ }^{59}$

- Kepastian (yaqin)

Perpaduan antara pengetahuan dan rasa cinta yang mendalam lagi dengan adanya perjumpaan secara langsung, maka tertanamlah dalam qalb perasaan yang mantap tentang Allah. Perasaan mantapnya pengetahuan yang diperoleh dari pertemuan secara langsung itulah yang dinamakanalyaqin. Jadi, al-yaqin berarti perpaduan antara pengetahuan yang luas serta mendalam dan rasa cinta serta rindu yang mendalam pula sehingga tertanamlah dalam jiwanya perjumpaan secara langsung dengan Tuhannya. Dalam pandangan al-Junaid, yaqin adalah tetapnya ilmu di dalam hati, tidak berbalik, tidak berpindah dan tidak berubah. Dengan demikian, yaqin adalah kepercayaan yang kokoh, tak tergoyahkan tentang kebenaran pengetahuan yang dimiliki. 60 


\section{Kesimpulan}

Dapat disimpulkan bahwa tasawuf adalah ilmu yang mempelajari manusia untuk mendekatkan diri kepada Allah dalam keadaan yang dekat-sedekatnya. Dalam ilmu Tasawuf, maqamat berarti tingkatan atau kedudukan hamba dalam pandangan Allah berdasarkan apa yang telah diusahakan, baik melalui riyadhah, ibadah, maupun mujahadah. Di samping itu, maqamat berarti jalan panjang atau fase-fase yang harus ditempuh oleh seorang sufi untuk berada sedekat mungkin dengan Allah. Maqam dilalui seorang hamba melalui usaha yang sungguh-sungguh dalam melakukan sejumlah kewajiban yang harus ditempuh dalam jangka waktu tertentu. Seorang hamba tidak akan mencapai maqam berikutnya sebelum menyempurnakan maqam sebelumnya. Ciri khas maqamat adalah menetap. Maqamat yang dilalui oleh para sufi berbeda satu dengan yang lainnya, karena kondisi psikologis antara satu dengan lainnya tidak sama. Sedangkan ahwal adalah suatu keadaan atau kondisi jiwa yang dirasakan seseorang sufi yang mengiringi maqam tertentu dari sufi tersebut tanpa daya dan upaya. Ciri khusus hal ini adalah hanya sementara dan tidak bisa diusahakan.
Ahwal antara sufi satu dengan sufi yang lainnya.

\section{Referensi}

\footnotetext{
${ }^{1}$ Mahmud Yunus, Kamus Arab Indonesia, (Jakarta: Hidakarya Agung, 1990), h. 362

${ }^{2}$ Tim Penyusun MKD IAIN Sunan Ampel, Akhlak Tasawuf, (Surabaya: IAIN SA Press, 2011), h. 243

${ }^{3}$ Harun Nasution, Falsafat dan Mistisisme Dalam Islam, (Jakarta: Bulan Bintang, 1983), h. 62

${ }^{4}$ Harun Nasution, Falsafat dan Mistisisme..., h. 62

${ }^{5}$ Harun Nasution, Falsafat dan Mistisisme..., h. 62

${ }^{6}$ Abuddin Nata, Akhlak Tasawuf, (Jakarta: Rajawali Pers, 2011), h. 194

${ }^{7}$ Abuddin Nata, Akhlak Tasawuf..., h.194

${ }^{8}$ Mahmud Yunus, Kamus Arab..., h. 79

${ }^{9}$ Abuddin Nata, Akhlak Tasawuf..., h. 198

${ }^{10}$ Harun Nasution, Falsafat dan Mistisisme..., h. 67

${ }^{11}$ Abul Qasim Abdul Karim Hawazn AlQusyairi An-Naisaburi, Risalah Qusyairiyah; Sumber Kajian Ilmu Tasawuf, Terj. Umar Faruq, (Jakarta: Pustaka Amani, 2007), Cet. II, h. 116

${ }^{12}$ Mulyadhi Kartanegara,, Menyelami Lubuk Tasawuf, (Jakarta: Erlangga, 2006), h. 192

${ }^{13}$ Tim penyusun MKD IAIN Sunan

Ampel, Akhlak..., h. 244

${ }^{14}$ Simuh, Tasawuf dan Perkembangannya Dalam Islam, (Jakarta: RajaGrafindo Persada, 1997), h. 52

${ }^{15}$ Al-Ghazali, Mutiara Ihya' 'Ulumuddin, terj. Irwan Kurniawan, (Bandung: Mizan, 2002), h. 306

${ }^{16}$ Lihat, QS. An-Nur: 31 dan Ali Imron: 135

${ }^{17}$ Amin $\quad$ Syukur, Zuhud di Abad Modern, (Yogyakarta: Pustaka Pelajar, 2004), h.1

${ }^{18}$ Muhammad Muntahibun Nafis, Kontemplasi Jurnal Ilmu-Ilmu Ushuluddin, (Tulungagung: STAIN Tulungagung, 2013), h. 230 ${ }^{19}$ Al-Ghazali, Mutiara Ihya' 'Ulumuddin..., h. 339

${ }^{20}$ Harun Nasution, Falsafat dan Mistisisme..., h. 64

${ }^{21}$ Mulyadhi Kartanegara,, Menyelami..., h. 186

${ }^{22}$ Lihat, QS. An-Nisa': 77 dan al-Taubah:

${ }^{23}$ Abuddin Nata, Akhlak Tasawuf..., h. 199
} 




